This is the version of the article accepted for publication in Journal of Religion in Africa Vol. 46 (2-3), 121-128 published by Brill. Available at: $10.1163 / 15700666-12340078$

Accepted version downloaded from SOAS Research Online: http://eprints.soas.ac.uk/23816/

\title{
Introduction: Religion and Masculinities in Africa
}

\section{Dorothea Schulz (University of Cologne) and Marloes Janson (SOAS, University of London)}

At a time when born-again Christianity and reformist Islam are among the fastest-growing religious traditions in present-day Africa, more attention needs to be paid to religion as a crucial factor in the dynamic process of constructing, challenging, and transforming gendered identities. So far few studies have addressed issues of gender beyond the all-too-popular focus on Christian and Muslim women who 'resist' the dominant patriarchal order, or, for that matter who 'liberate' themselves from the yoke of 'conservative' gender ideologies articulated by Christian and Muslim communities in sub-Saharan Africa. This special issue seeks to make up for the biased representations of the interplay between constructions of gender identities and religious practices and understandings that have been generated by conventional research preoccupations, agendas, and concepts. Specifically, the contributions bring together three lines of exploration that Africanist research has tended to treat separately. These are firstly, the study of gender; secondly, masculinity studies; and thirdly, the study of religious reformist trends that over the last decades have shaped discourses within Christian and Muslim communities, and also at the interface between Christianity and Islam. ${ }^{i}$

As Miescher, Manuh and Cole argue in their pioneering volume Africa after Gender?, gender has become one of the most dynamic areas of Africanist research today (2007: 2). Replacing women's studies and feminist approaches, the study of gender and gender relations gained popularity in the 1980s, emphasizing the difference between biological sex and culturally constructed notions of masculinity and femininity (see Cornwall 2005; Ouzgane and Morrell 2005). Nevertheless, within African Studies gender has for a long time been equated with women.

We fell in a similar pitfall during our workshop Reconfiguring Gender Relations in Muslim Africa, which we organized at the International Institute for the Study of Islam in the Modern World (ISIM), in Leiden, the Netherlands, in 2006. ${ }^{\text {ii }}$ This collection of essays is the result of the workshop Religion and Masculinities in Africa that we organized at the School of Oriental and African Studies (SOAS), University of London, in September 2014, with the purpose of moving 
This is the version of the article accepted for publication in Journal of Religion in Africa Vol. 46 (2-3), 121-128 published by Brill. Available at: $10.1163 / 15700666-12340078$

Accepted version downloaded from SOAS Research Online: http://eprints.soas.ac.uk/23816/

beyond our earlier tendency to study gender relations from the perspective of women. We sought to address how changes in the meanings of gender and in religious discourse and practice affect both Christian and Muslim men in sub-Saharan Africa.

The contributions draw on insights generated by masculinity studies (e.g. Kimmel 1987, Connell 1995; Berger, Wallis, and Watson 1995) that, from the 1990s onwards, have influenced anthropological research and theorizing (e.g. Cornwall and Lindisfarne 1994; Morell 2001; Lindsay and Miescher 2003; Miescher 2005; Ouzgane and Morrell 2005; Uchendu 2008). As a result, African male actors were no longer treated as the unmarked 'default option', but were explored as 'engendered and engendering persons' (Gutmann 1997), a conception that opened up possibilities to account for substantial differences between male actors, with regard to experiences, practices and their respective understandings of what it means to be a man. Over the past decade, pioneering work at the interface of gender theory and masculinity studies has illustrated the constructed character of binary conceptions of gender identity. Drawing on Butler's (1990) work, new approaches to gender as performance posit the malleable, historically and socially contingent, and 'constructed' nature of male and female identity 'performances'.

In spite of these valuable developments, masculinity studies still suffer from the tendency to theorize masculinity by drawing on empirical data from Europe, North America, and Australia, while paying little attention to the variety of men's practices and subjectivities in African societies (but see Morrell 1998, 2001; Reid and Walker 2005). The few exceptions to this trend are studies on masculinity in South Africa, which offer a somewhat skewed portrayal of masculinity ideals insofar as they are largely preoccupied with the relationship between masculinity and (sexual) violence exerted on women (Morell 2001: 12). The contributions to this special issue move beyond the 'compartmentalization' (Broqua and Doquet 2013: ii-iii) of masculinity studies and expand the regional focus of Africanist masculinity studies beyond South Africa. Our emphasis is on how masculinity is discursively shaped and enacted in a Christianmajority setting (Zambia), Muslim-majority settings (the Gambia, Mali), as well as settings with a more or less equal division between Christians and Muslims (Nigeria and Tanzania).

\section{Moving Away from the 'Cake Mix' Approach}

Studies on gender and religion often content themselves with what one could call the 'cake mix version' of gender studies: add women to the analysis of religion and stir. Typical of the 'cake 
This is the version of the article accepted for publication in Journal of Religion in Africa Vol. 46 (2-3), 121-128 published by Brill. Available at: $10.1163 / 15700666-12340078$

Accepted version downloaded from SOAS Research Online: http://eprints.soas.ac.uk/23816/

mix' approach is that it treats gender as being reducible to women, and therefore fails to engage gender analytically as a mode of generating and reflecting historically determinate forms of manhood, and notions of masculinity and femininity.

In contrast, the contributions to this special issue explore how understandings and practices of masculinity have been molded and transformed through religious reform in Africa; and how changing notions, norms, and social practices of masculinity shape and are shaped by religious discourse, innovation, and contestation. Considering that religious reformist trends often articulate gender-specific notions of surrender to God's directives and prescripts, this raises the question as to how notions of ideal manhood propagated by religious institutions relate to men's self-understandings and realizations of manhood in everyday life.

Conceiving of masculinity as a special disposition (i.e. ways of feeling, thinking, and comporting oneself as a male person) that refers to 'a cluster of norms, values, and behavioral patterns expressing explicit and implicit expectations of how men should act and represent themselves to others' (Miescher and Lindsay 2003: 4), the case studies insist on the multiplicity of these dispositions and related norms, and hence on coexisting 'masculinities' (Connell 1995; Morrell 2001). Closer investigation of the field of multiple, dominant, submerged, and subaltern ideals of masculinity, as well as femininity, allows us to understand them in their mutually constitutive, malleable, and dynamic relationship - and hence avoid any 'add and stir' version of gender that, ultimately, results in an impoverished and static form of men's and women's studies.

All contributions show the importance of exploring changing constructions of masculinity from a diachronic and long-term perspective. During the colonial period, new dimensions were added to local notions of gender and today the breadwinner model is widely accepted in both Christian and Muslim circles to the extent that it has become a dominant element within gender ideology (Lindsay 2007). Indeed, colonial legacies, institutions, and stereotypes continue to inform present-day practices of masculinity. With the Structural Adjustment Programmes and neo-liberal reforms in the 1980s and 1990s, an increasing number of men had difficulties in living up to the norm (see Cornwall 2016). Men had to reinvent themselves, and religion seems to provide them with the tools to do so by offering an avenue to realize themselves as new moral subjects . As Becker illustrates, the changing gender dynamics coincides with feelings of nostalgia in Tanzania. 
This is the version of the article accepted for publication in Journal of Religion in Africa Vol. 46 (2-3), 121-128 published by Brill. Available at: $10.1163 / 15700666-12340078$

Accepted version downloaded from SOAS Research Online: http://eprints.soas.ac.uk/23816/

Starting from Connell's (1995: 71) call for an exploration of the processes and relationships through which men and women conduct gendered lives, Van Klinken's and Janson's contributions demonstrate that religious reform movements highlight a similar conception of gender identities, stressing that the search for gender-specific realizations of piety is an on-going process. Here, an analogy exists between Pentecostal and Muslim conceptions of reform in terms of a moral self-transformation and continuous renewal. Through religious practice Pentecostal Christians and reformist Muslims dissociate themselves, whether symbolically or actually, from their past life in the form of local cultural and religious traditions. This rupture with the past - a precondition for becoming born again (cf. Meyer 1998) coincides with the development of new moral subjectivities. The Pentecostal claim that one can be 'forever born again ... and again and again' (see Van Klinken's contribution) fits in well with the central notion in masculinity theory that men are always in the (re)making since masculinity is a fluid concept rather than an immutable essence.

\section{Studying Masculinities at the Intersection of Multiple Markers of Difference}

Although this special issue adopts a gender analytical lens and focuses on relational constructions of masculinity, the contributions also opt for an intersectional approach, stressing that religious actors' identities are not molded by gender alone (see also Whitehead and Barrett 2001: 10-14). They highlight other markers and axes of social difference, such as age, generation, race, ethnicity, and class. For example, Harris's, Wignall's, and Diallo and Schulz's contributions illustrate how differently fathers and sons conceive of themselves as men and as proper believers. In present-day Nigeria, the Gambia and Mali, adult and unmarried 'young' men face considerable challenges in struggling to live up to the expectations put on them as breadwinners and household heads. Because of their inability to provide for their families and to support their sons in establishing their own households, fathers have lost respect in their sons' eyes. Yet, the 'crisis of masculinity' (Hearn 1999; see also Becker's contribution) shows itself not only in the crisis of fatherly authority, but also in young men's self-understandings as autonomous actors who strive for autonomy and acceptance as full-blown members of society in a situation shaped by the HIV/AIDS pandemic (Chitando 2007; Uchendu 2008) and neoliberal reform (e.g. Schulz 2011, 2012: ch.3; Cornwall 2016). As Wignall points out, adopting a religious identity offers young men new ways to respond to these challenges, and to claim an active role as 'makers and 
This is the version of the article accepted for publication in Journal of Religion in Africa Vol. 46 (2-3), 121-128 published by Brill. Available at: $10.1163 / 15700666-12340078$

Accepted version downloaded from SOAS Research Online: http://eprints.soas.ac.uk/23816/

breakers' (Honwana and De Boeck 2005) of social norms. Moreover, as illustrated by Diallo and Schulz, considerable differences exist between different categories of young men, with respect to their chances to find a way out of the situation of crisis, and also with respect to the strategies they adopt in their self-understanding as agents of religious and moral renewal.

Thus, paying attention to markers of social differentiation may enlarge our understanding of how competing masculinities rest on, and define in turn, power differentials within the family and society at large. Here, we need a systematic account of instances of intergenerational conflicts over changing ideals of religiosity and masculinity from the vantage point of both youth and elders - a perspective that has been pervasive in much classical anthropological scholarship (e.g. Meillassoux 1981), yet not with regard to religious reform and masculinity.

A final perspective in this special issue concerns changes in moral agency and interpersonal relations in relation to broader societal transformations and political processes. Since the religious revival of the 1970s, Christian and Muslim reform movements and idioms have gained prominence in politics and social life throughout Africa. The new public visibility of religion is closely connected to the (re)negotiation of religious subjectivities. The case studies covered in this special issue take the dialectical constitution of individual and social, private and public forms of religiosity as a starting place to move beyond a narrow focus on personal 'politics of piety' (Mahmood 2005). We take masculinity as a heuristic concept to show how religious reform plays itself out at the macro-political level of activism, and feeds back into interpersonal relations and an individual quest for moral transformation (Schulz 2012; see Van Klinken's, Becker's, and Janson's contributions).

\section{Concluding Remarks}

According to Miescher, Manuh and Cole (2007: 3), to advance the discourse on gender in Africa requires moving beyond essentialist interpretations, simple dichotomies, entrenched debates, and the polarizing identity politics that have paralyzed past discussion. Now, almost a decade later, scholarship on gender in Africa is still marked by the tendency to describe men as an unmarked, universal category. By adopting an approach that bridges boundaries between the sexes, different religious traditions, disciplinary boundaries, as well as North-South divisions, and by locating notions of masculinity within religious institutions, the life cycle, power relations and economic structures, this special issue illustrates the centrality of religiously mediated masculinities to 
This is the version of the article accepted for publication in Journal of Religion in Africa Vol. 46 (2-3), 121-128 published by Brill. Available at: $10.1163 / 15700666-12340078$

Accepted version downloaded from SOAS Research Online: http://eprints.soas.ac.uk/23816/

understandings of the articulation between changing interpersonal relations and broader societal transformations and political processes in Africa in the $21^{\text {st }}$ century.

\section{Bibliography}

Berger, Maurice, Brian Wallis, and Simon Watson. 1995. 'Introduction'. In Maurice Berger, Brian Wallis, and Simon Watson (eds.), Constructing Masculinity. New York and London: Routledge, 1-7.

Broqua, Christophe and Anne Doquet. 2013. 'Examining Masculinities in Africa and Beyond'. Cahiers d'études Africaines LIII (1-2), No. 209-210, I-XXXII.

Butler, Judith. 1990. Gender Trouble: Femininity and the Subversion of Identity. New York: Routledge.

Chitando, Ezra. 2007. 'A New Man for a New Era? Zimbabwean Pentecostalism, Masculinities and the HIV Epidemic'. Missioanalia 35.3, 112-127.

Connell, Raewyn W. 1995. Masculinities. Cambridge: Polity Press.

Cornwall, A. (ed.) 2005. Readings in Gender in Africa. Bloomington: Indiana University Press; Oxford: James Currey.

Cornwall, Andrea. 2016. 'Introduction: Masculinities under Neoliberalism'. In Andrea Cornwall, Frank G. Karioris, and Nancy Lindisfarne (eds.), Masculinities under Neoliberalism. London: Zed Books, 1-28.

Cornwall, Andrea and Nancy Lindisfarne. 1994. 'Dislocating Masculinity: Gender, Power and Anthropology'. In Andrea Cornwall and Nancy Lindisfarne (eds.), Dislocating Masculinity. Comparative Ethnographies. London and New York: Routledge, 11-47.

Gutmann, Matthew C. 1997. 'Trafficking in Men: The Anthropology of Masculinity'. Annual Review of Anthropology 26, 385-409.

Hearn, Jeff. 1999. 'A Crisis in Masculinity, or New Agendas for Men?' In Sylvia Walby (ed.), New Agendas for Women. London: Palgrave Macmillan, 148-168.

Honwana, Alcinda and Filip De Boeck (eds.) 2005. Makers and Breakers: Children and Youth in Postcolonial Africa. Oxford: James Currey; Trenton: Africa World Press; Dakar: Codesria.

Janson, Marloes. 2016. "'How, for God's sake, can I be a good Muslim?": Gambian Youth in Search of a Moral Lifestyle'. Ethnography 17, 22-46.

Janson, Marloes and Akintunde Akinleye. 2015. 'The Spiritual Highway: Religious World Making in Megacity Lagos (Nigeria)'. Material Religion 11.4, 550-562.

Janson, Marloes and Dorothea Schulz (eds.) 2008. Special Issue on Reconfiguring Gender Relations in Muslim Africa. Journal for Islamic Studies 28.

Kimmel, Michael S. (ed.) 1987. Changing Men: New Directions in Research on Men and Masculinity. Thousand Oaks, CA: Sage Publications.

Larkin, Brian and Birgit Meyer. 2006. 'Pentecostalism, Islam and Culture: New Religious Movements in West Africa'. In E. K. Akyeampong (ed.), Themes in West African History. Oxford: James Currey, 286-312.

Lindsay, Lisa A. 2007. 'Working with Gender: The Emergence of the "Male Breadwinner" in Colonial Southwestern Nigeria'. In Catherine M. Cole, Takyiwaa Manuh, and Stephan Miescher (eds.), Africa After Gender? Bloomington: Indiana University Press, 241-252. 
This is the version of the article accepted for publication in Journal of Religion in Africa Vol. 46 (2-3), 121-128 published by Brill. Available at: $10.1163 / 15700666-12340078$

Accepted version downloaded from SOAS Research Online: http://eprints.soas.ac.uk/23816/

Mahmood, Saba. 2005. Politics of Piety. The Islamic Revival and the Feminist Subject. Princeton: Princeton University Press.

Meillassoux, Claude. 1981. Maidens, Meal and Money. Capitalism and the Domestic

Community. Cambridge: Cambridge University Press.

Meyer, Birgit. 1998. "“Make a Complete Break with the Past”. Memory and Post-Colonial

Modernity in Ghanaian Pentecostalist Discourse'. Journal of Religion in Africa 28.3, 316-349.

Miescher, Stephan F. 2005. Making Men in Ghana. Bloomington: Indiana University Press.

Miescher, Stephan, F. Takyiwaa Manuh, and Catherine M. Cole. 2007. 'Introduction: When was

Gender?' In Catherine M. Cole, Takyiwaa Manuh, and Stephan M. Miescher (eds.), Africa

After Gender? Bloomington: Indiana University Press, 1-14.

Miescher, Stephan F. and Lisa A. Lindsay. 2003. 'Introduction: Men and Masculinities in

Modern African History.' In Lisa A. Lindsay and Stephan F. Miescher (eds.), Men and

Masculinities in Modern Africa. Portsmouth, NH: Heinemann, 1-29.

Morell, Robert. 1998. 'Of Boys and Men: Masculinity and Gender in Southern African Studies'. Journal of Southern African Studies 24.4, 605-630.

. (ed.) 2001. Changing Men in Southern Africa. Pietermaritzburg and London: University of

Natal Press and Zed Books.

Ouzgane, Lahoucine and Robert Morrell (eds.) 2005. African Masculinities. Men in Africa from

the Late Nineteenth Century to the Present. New York: Palgrave Macmillan; Scottsville:

KwaZulu-Natal Press.

Peel, J.D.Y. 2011. 'Un siècle d'interactions entre Islam et Christianisme dans l'espace Yoruba'. Politique africaine 123, 27-50.

Reid, Graeme and Liz Walker (eds.) 2005. Men Behaving Differently: South African Men since 1994. Cape Town: Double Stery Books.

Schulz, Dorothea. 2011. 'Mapping Cosmopolitan Identities: Rap Music and Male Youth Culture in Mali'. In Eric Charry (ed.), Hip Hop Africa: New African Music in a Globalizing World.

Bloomington: Indiana University Press, 129-146. 2012. Muslims and New Media in West Africa: Pathways to God. Bloomington: Indiana University Press.

Uchendu, Egodi (ed.) 2008. Masculinities in Contemporary Africa. Dakar: Codesria.

Whitehead, Stephen M. and Frank J. Barrett. 2001. 'The Sociology of Masculinity'. In Stephen

M. Whitehead and Frank J. Barrett (eds.), The Masculinities Reader. Cambridge: Polity Press, $1-26$.

Notes

${ }^{\mathrm{i}}$ For recent studies that treat Christianity and Islam in Africa as mirror images, see Larkin and Meyer 2006; Peel 2011; Janson and Akinleye 2015; Janson 2016.

ii This workshop resulted in a special issue of Journal for Islamic Studies (2008), co-edited by Marloes Janson and Dorothea Schulz. 